\title{
Four types of cannabimimetic indazole and indole derivatives, ADB-BINACA, AB-FUBICA, ADB-FUBICA, and AB-BICA, identified as new psychoactive substances
}

\author{
Zhenhua Qian $^{1} \cdot$ Zhendong Hua $^{1} \cdot$ Cuimei Liu $^{1} \cdot$ Wei Jia $^{1}$
}

Received: 19 September 2015/Accepted: 10 October 2015/Published online: 13 November 2015

(C) Japanese Association of Forensic Toxicology and Springer Japan 2015

\begin{abstract}
We identified four cannabimimetic indazole and indole derivatives in new illegal psychoactive substances seized from a clandestine laboratory in China. These four derivatives included $N$-(1-amino-3,3-dimethyl-1-oxobutan-2yl)-1-benzyl- $1 H$-indazole-3-carboxamide (ADB-BINACA, 1), $\quad N$-(1-amino-3-methyl-1-oxobutan-2-yl)-1-(4-fluorobenzyl)- $1 H$-indole-3-carboxamide (AB-FUBICA, 2), $N$-(1amino-3,3-dimethyl-1-oxobutan-2-yl)-1-(4-fluorobenzyl)$1 H$-indole-3-carboxamide (ADB-FUBICA, 3), and $N$-(1amino-3-methyl-1-oxobutan-2-yl)-1-benzyl-1 $H$-indole-3carboxamide (AB-BICA, 4). These compounds were identified by liquid chromatography-high-resolution mass spectrometry, gas chromatography-mass spectrometry, and nuclear magnetic resonance spectroscopy. No chemical or pharmacological data about compound $\mathbf{4}$ has appeared until now, making this the first report on this compound. Compounds $\mathbf{1}, \mathbf{2}$, and 3 have previously been reported to have a high affinity for cannabinoid $\mathrm{CB}_{1}$ and $\mathrm{CB}_{2}$ receptors, but this is the first report of their presence in illegal products.
\end{abstract}

Keywords $N$-(1-Amino-3,3-dimethyl-1-oxobutan-2-yl)-1benzyl- $1 \mathrm{H}$-indazole-3-carboxamide (ADB-BINACA) $\cdot \mathrm{N}$ (1-Amino-3-methyl-1-oxobutan-2-yl)-1-(4-fluorobenzyl)$1 H$-indole-3-carboxamide (AB-FUBICA) $\cdot N$-(1-Amino3,3-dimethyl-1-oxobutan-2-yl)-1-(4-fluorobenzyl)-1H-

Electronic supplementary material The online version of this article (doi:10.1007/s11419-015-0297-2) contains supplementary material, which is available to authorized users.

Wei Jia

weijia_nnl@163.com

1 National Narcotic Laboratory, Drug Intelligence and Forensic Center of Minister of Public Security, No. 18 Dongbeiwang West Round, Haidian District, Beijing 100193, China indole-3-carboxamide (ADB-FUBICA) $\cdot N$-(1-Amino-3methyl-1-oxobutan-2-yl)-1-benzyl-1H-indole-3carboxamide (AB-BICA) - Synthetic cannabinoid . New psychoactive substance

\section{Introduction}

A wide variety of new psychoactive substances (NPSs) has emerged around the world over the past few years, and many of the existing drugs have been replaced by other new drugs in a short period of time [1-6]. By July 2015, 96 countries and territories reported over 540 NPSs to UNODC, far exceeding the 234 substances currently controlled under the International Drug Conventions [3]. Synthetic cannabinoids are cannabimimetic compounds originally synthesized for medical research, but now have become the largest and most dynamic group of NPSs. Since the identification of the first synthetic cannabinoid in 2008, more than 130 synthetic cannabinoids have been reported to the European Monitoring Centre for Drugs and Drug Addiction (EMCDDA) [1]. According to the UNODC Global Synthetic Monitoring: Analyses, Reporting, and Trends (SMART) program, 184 synthetic cannabinoids (34\% of the total number of NPSs reported worldwide) have been detected as psychoactive ingredients in herbal products or chemical powder around the world up to now [3].

In June 2015, a clandestine laboratory was dismantled in Hubei Province of China, and about $20 \mathrm{~kg}$ of NPS powder samples were seized. About 200 unknown samples were submitted to the national narcotic laboratory of Minister of Public Security for analysis. After a series of complicated analyses using liquid chromatography-high-resolution mass spectrometry (LC-HR-MS), gas chromatography- 
mass spectrometry (GC-MS), and nuclear magnetic resonance spectroscopy (NMR), about 30 species of synthetic cannabinoids were disclosed, including four new types of synthetic cannabinoids, which were $N$-(1-amino-3,3-dimethyl-1-oxobutan-2-yl)-1-benzyl-1 $H$-indazole-3-carboxamide (ADB-BINACA, 1), $N$-(1-amino-3-methyl-1-oxobutan2-yl)-1-(4-fluorobenzyl)-1 $H$-indole-3-carboxamide (ABFUBICA, 2), $N$-(1-amino-3,3-dimethyl-1-oxobutan-2-yl)1-(4-fluorobenzyl)-1 $H$-indole-3-carboxamide (ADBFUBICA, 3), and $N$-(1-amino-3-methyl-1-oxobutan-2-yl)1-benzyl-1H-indole-3-carboxamide (AB-BICA, 4). All of them represent the indazole or indole analogues of $\mathrm{AB}$ FUBINACA or ADB-FUBINACA [7-10]. There has been no synthetic, chemical, or biological information about compound 4 until now; this is the first report of this compound. Compounds $\mathbf{1}$ and $\mathbf{2 / 3}$ were synthesized by Pfizer in 2009 [10] and Banister in 2015 [7], respectively, and were reported as potent cannabinoid $\mathrm{CB}_{1}$ and $\mathrm{CB}_{2}$ receptor modulators. This is the first report of their detection in illegal products and their mass spectra are discussed in detail in this article. The structures of compounds 1-4 were elucidated by comparing to the LC-MS, GC-MS, and NMR data with those of compound $\mathbf{5}$, which is a known synthetic cannabinoid $N$-(1-amino-3-methyl-1-oxobutan-2yl)-1-(4-fluorobenzyl)-1 $H$-indazole-3-carboxamide (ABFUBINACA) [7, 9].

In this article, we described our identification of the four newly detected synthetic cannabinoid compounds in detail. The structures of compounds 1-5 are shown in Fig. 1.

\section{Materials and methods}

\section{Chemicals and reagents}

Methanol and formic acid were obtained from Merck Chemicals (Darmstadt, Germany). Acetonitrile was obtained from Fisher Scientific (Aalst, Belgium). Deuterated dimethyl sulfoxide (DMSO- $d_{6}, 99.9 \%$ ) was purchased from Cambridge Isotope Laboratories (Tewksbury, MA, USA). All solvents and reagents used in the analyses were of HPLC grade. Distilled water was obtained by reverse diffusion in a Millipore system (EMD Millipore, Billerica, MA, USA).

\section{Sample preparation}

For GC-MS analysis, $5 \mathrm{mg}$ of the powder-type product was extracted with $5 \mathrm{~mL}$ of methanol under ultrasonication for $10 \mathrm{~min}$. For LC-MS analysis, the prepared solution was diluted to $1 \mu \mathrm{g} / \mathrm{mL}$ with methanol and passed through a centrifugal filter $(0.22 \mu \mathrm{m}$ filter unit; EMD Millipore). For

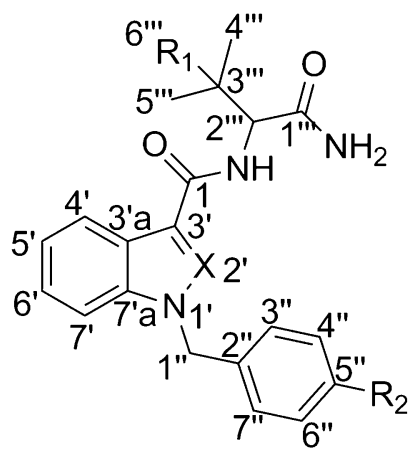

$$
\begin{aligned}
& \mathrm{R}_{1}=\mathrm{CH}_{3}, \mathrm{R}_{2}=\mathrm{H}, \mathrm{X}=\mathrm{N}(\text { ADB-BINACA, 1) } \\
& \mathrm{R}_{1}=\mathrm{H}, \mathrm{R}_{2}=\mathrm{F}, \mathrm{X}=\mathrm{CH}(\mathrm{AB}-\mathrm{FUBICA}, 2) \\
& \mathrm{R}_{1}=\mathrm{CH}_{3}, \mathrm{R}_{2}=\mathrm{F}, \mathrm{X}=\mathrm{CH}(\text { ADB-FUBICA, 3) } \\
& \mathrm{R}_{1}=\mathrm{H}, \mathrm{R}_{2}=\mathrm{H}, \mathrm{X}=\mathrm{CH}(\mathrm{AB}-\mathrm{BICA}, 4) \\
& \mathrm{R}_{1}=\mathrm{H}, \mathrm{R}_{2}=\mathrm{F}, \mathrm{X}=\mathrm{N}(\text { AB-FUBINACA, 5) }
\end{aligned}
$$

Fig. 1 Structures of the newly detected compounds 1-4 as well as a detected but known compound $\mathbf{5}$

NMR analysis, about $15 \mathrm{mg}$ of the sample powder was dissolved in $1 \mathrm{~mL}$ of deuterated DMSO.

\section{Analytical conditions}

Liquid chromatography-high-resolution mass spectrometry (LC-HR-MS) analysis was carried out using a Waters Acquity UPLC (Waters, Milford, MA, USA) coupled with an AB Sciex TripleTOF 5600 detector (AB Sciex, Framingham, MA, USA). Separation was performed at $40{ }^{\circ} \mathrm{C}$ with an Acquity UPLC $\mathrm{CSH}^{\mathrm{TM}} \mathrm{C} 18$ column $(10 \mathrm{~cm} \times 2.1 \mathrm{~mm}$ i.d., $1.7 \mu \mathrm{m}$ particle diameter; Waters $)$. For gradient elusion the mobile phases $0.1 \%$ formic acid in water (A) and acetonitrile (B) were used with the time program: 0-1.5 min, $2 \% \mathrm{~B} ; 1.5-6.5 \mathrm{~min}, 2-90 \% \mathrm{~B}$; 6.5-9.4 min, $90 \% \mathrm{~B} ; 9.4-9.5 \mathrm{~min}, 90-2 \% \mathrm{~B}$; 9.5-12 min, $2 \%$ B. The flow rate was $0.4 \mathrm{~mL} / \mathrm{min}$. The Triple TOF instrument was operated by electrospray ionization (ESI) in the positive mode. Ion spray voltage, $5.5 \mathrm{kV}$; turbo spray temperature, $600{ }^{\circ} \mathrm{C}$; nebulizer gas (Gas 1), $50 \mathrm{psi}$; heater gas (Gas 2), 50 psi; curtain gas, 30 psi. Nitrogen was used as the nebulizer and auxiliary gas. Typical information dependent acquisition consisted of two steps: the acquisition of a survey full scan spectrum and then a tandem mass spectrometry (MS/MS) experiment. Full scan experiment was operated under the high resolution mode. The optimized declustering potential and collision energy were set at 80 and $5 \mathrm{~V}$, respectively. In the second experiment, a sweeping collision energy setting at $25 \pm 15 \mathrm{~V}$ was applied for collision-induced dissociation (CID) to obtain the fragment ions from the ions in the preceding scan. The full scan and the MS/MS experiment were both operated in the mass range of $m / z 100-1000$. Injection volume was $1 \mu \mathrm{L}$. 
GC-MS analysis was performed using a Shimadzu 2010 gas chromatograph coupled with a QP2010 Plus mass selective detector (Shimadzu, Kyoto, Japan). The extracts were injected in split mode (1:20). Chromatographic separation was carried out on a DB-5 MS capillary column (30 $\mathrm{m} \times 0.25 \mathrm{~mm}$ i.d., $0.25 \mu \mathrm{m}$ film thickness; J\&W Scientific, Agilent Technologies, Palo Alto, CA, USA), and helium at a constant flow rate of $1.0 \mathrm{~mL} / \mathrm{min}$ was used as the carrier gas. The initial column temperature $\left(60^{\circ} \mathrm{C}\right)$ was increased to $280{ }^{\circ} \mathrm{C}$ at a rate of $20{ }^{\circ} \mathrm{C} / \mathrm{min}$, and held at $280{ }^{\circ} \mathrm{C}$ for $20 \mathrm{~min}$, then ramped up to $300{ }^{\circ} \mathrm{C}$ at a rate of $10{ }^{\circ} \mathrm{C} / \mathrm{min}$, and finally held at $300{ }^{\circ} \mathrm{C}$ for $20 \mathrm{~min}$. The $\mathrm{GC}$ injector and transfer line were maintained at $280{ }^{\circ} \mathrm{C}$ and $250{ }^{\circ} \mathrm{C}$, respectively. Ionization energy was set at $70 \mathrm{eV}$ and positive ions were analyzed. Acquisition was carried out in a scan mode range of $\mathrm{m} / \mathrm{z}, 35-500$. Injection volume was $1 \mu \mathrm{L}$.

The NMR spectra were obtained on an Avance III 400 spectrometer (Bruker, Bremen, Germany). Assignments were made via ${ }^{1} \mathrm{H} \quad \mathrm{NMR},{ }^{13} \mathrm{C}$ NMR, distortionless enhancement by polarization transfer (DEPT), HH correlation spectroscopy (HH COSY), heteronuclear singlequantum correlation spectroscopy (HSQC), and heteronuclear multiple-bond correlation spectroscopy (HMBC) spectra.

\section{Results and discussion}

\section{LC-HR-MS(/MS) and GC-MS analyses of compounds 1-5}

Firstly, exact molecular mass numbers of compounds 1-5 were confirmed by measurements in the full scan MS mode using LC-HR-MS (Fig. 2). In addition, the accurate masses of the predominant product ions, obtained by the LCHR-MS/MS analysis (Fig. 3), provided further structural information. Based on the obtained exact molecular masses, chemical formulae for protonated molecular ions and product ions of compounds $\mathbf{1} \mathbf{- 5}$ are summarized in Table 1 together with calculated mass numbers. The errors between the observed and theoretical mass numbers of all protonated molecular ions and fragment ions were smaller than $5 \mathrm{ppm}$. The LC-MS fragmentation routes of these five protonated compounds were proposed (Fig. 4).

For GC-MS analysis, total ion current chromatogram (TIC) and electron ionization mass spectra of compounds 1-5 are shown in Figs. 5 and 6, respectively. In each of all TIC chromatograms, only a single peak appeared (Fig. 5), showing that each sample contained a target compound with very high purity (probably more than $95 \%$ ). The GCMS fragmentation routes of these five compounds were also proposed (Fig. 6).
Confirmation of compound 5 and its similarity with compounds $1-4$

Compound $\mathbf{5}$ is a known compound; its structure was confirmed by the comparing its GC-MS and NMR data with the data of compound AB-FUBINACA reported by Uchiyama [9] and that in the GC-MS databases from Cayman Chemical [11]. However, high-resolution mass spectrum and MS/MS analysis of compound 5 have not been reported and are shown in Table 1, Figs. 2e and 3e; ions of $[\mathrm{M}+\mathrm{Na}]^{+}$and $[\mathrm{M}+\mathrm{H}]^{+}$were observed in the ESI mass spectrum (Fig. 2e). In the product ion mass spectrum (Fig. 3e), fragment ions at $\mathrm{m} / \mathrm{z} 352.1465\left(\mathrm{~B}_{5}\right)$, $324.1511\left(\mathrm{C}_{5}\right)$, and $253.0775\left(\mathrm{D}_{5}\right)$ were formed by the sequential loss of $\mathrm{NH}_{3}, \mathrm{CO}$ and amino-methylpropyl from the protonated molecule (Fig. 4). The product ion mass spectrum at $\mathrm{m} / \mathrm{z} 109.0453\left(\mathrm{E}_{5}\right)$ was a rearrangement product of 1-fluoro-4-methylbenzene. The mass difference value between product ions $m / z 253.0775\left(\mathrm{D}_{5}\right)$ and $109.0453\left(\mathrm{E}_{5}\right)$ was 144.0324 , which indicated the indazolecarbaldehyde moiety.

Great similarities were found for the MS and NMR spectra of compounds $\mathbf{1 - 5}$, which revealed the structure similarity among these five compounds. For example, the same neutral loss of ammonia $\left[\mathrm{M}+\mathrm{H}-\mathrm{NH}_{3}\right]{ }^{+}$were observed in the LC-MS spectra (Figs. 2, 3), which corresponds to the loss of amino side chain. In addition, the same unsaturation degrees of 10 were observed. Therefore, the structure of four unknown compounds 1-4 were elucidated by comparing the MS and NMR spectral data with the known compound $\mathbf{5}$.

\section{Identification of compound 1}

The LC-MS and GC-MS spectra of compound $\mathbf{1}$ are shown in Figs. 2a, 3a, and 6a, respectively. The chemical structure of compound $\mathbf{1}$ was predicted by comparing its LC-MS and GC-MS spectra with those of compound 5 (AB-FUBINACA) (Figs. 2e, 3e, 6e). The accurate mass spectrum of compound 1 was measured by LC-HR-MS/ MS in the positive mode. The ion peak observed at $m / z, 365.1979\left(\mathrm{~A}_{1}\right)$ (Table 1) suggested that the protonated molecular formula of the compound was $\mathrm{C}_{21} \mathrm{H}_{25} \mathrm{~N}_{4} \mathrm{O}_{2}{ }^{+}$ (calcd. 365.1972). Product ions at $m / z 91.0546\left(\mathrm{E}_{1}\right), 235.0870$ $\left(\mathrm{D}_{1}\right)$, and $320.1764\left(\mathrm{C}_{1}\right)$ were found in the LC-HR-MS/MS spectrum (Fig. 3a). The product ion at $m / z 91.0546\left(\mathrm{E}_{1}\right)$ (predicted chemical formula: $\mathrm{C}_{7} \mathrm{H}_{7}{ }^{+}$) indicated the presence of an un-substituted benzyl moiety. The mass difference value between product ions at $m / z, 235.0870\left(\mathrm{D}_{1}\right)$ and $91.0546\left(\mathrm{E}_{1}\right)$ was 144.0324, which was identical with that between $253.0775\left(\mathrm{D}_{5}\right)$ and $109.0453\left(\mathrm{E}_{5}\right)$; compound 1 was deduced to have the same indazole-carbaldehyde moiety as compound 5. The difference value between product ions $\mathrm{C}_{1}$ 

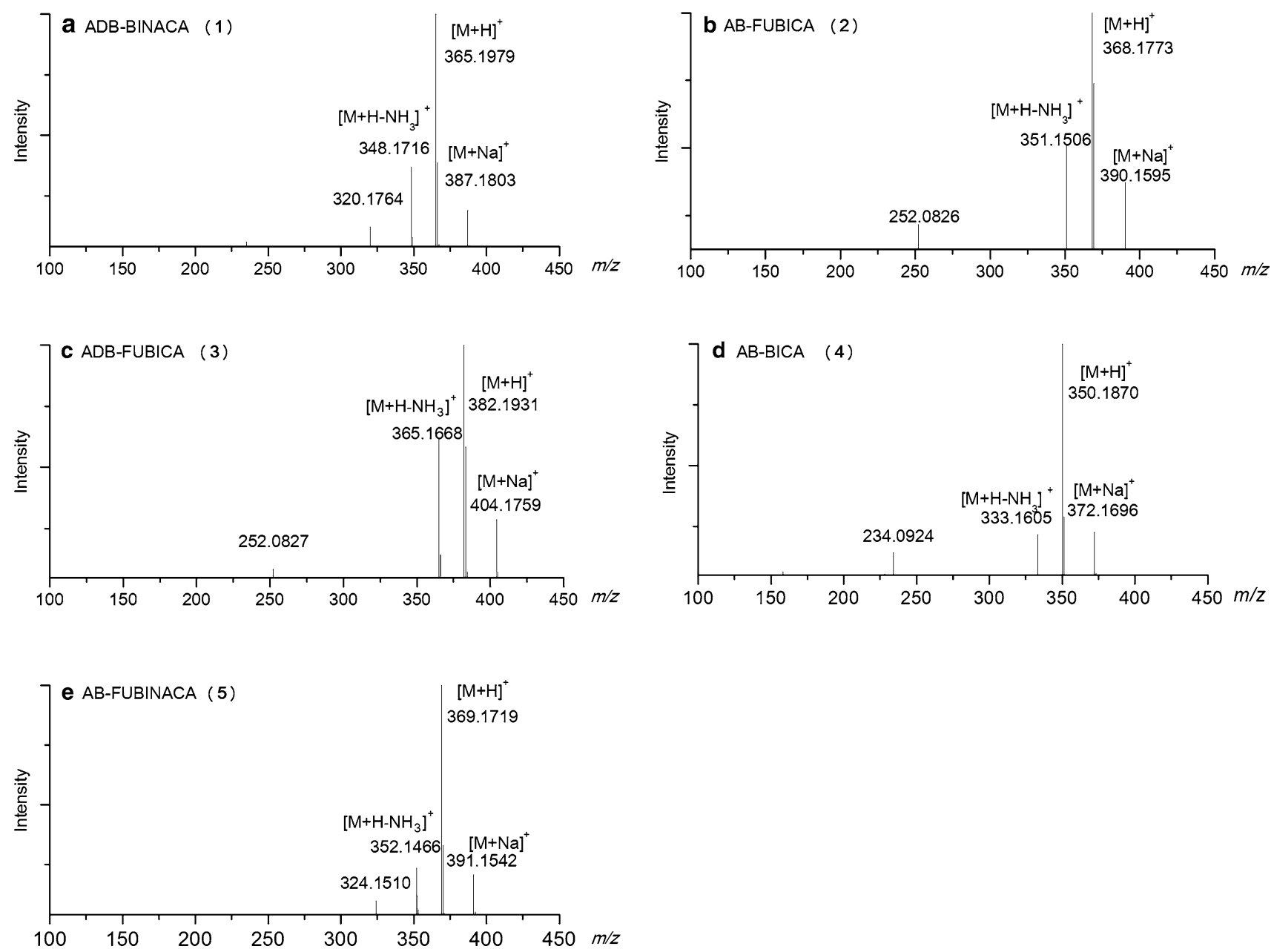

Fig. 2 Mass spectra of compounds 1-5 obtained by liquid chromatography-high resolution-mass spectrometry (LC-HR-MS) in the single stage mode

$\left(\mathrm{C}_{20} \mathrm{H}_{22} \mathrm{~N}_{3} \mathrm{O}^{+}\right)$and $\mathrm{D}_{1}\left(\mathrm{C}_{15} \mathrm{H}_{11} \mathrm{~N}_{2} \mathrm{O}^{+}\right)$of compound 1 was higher than that between product ions $\mathrm{C}_{5}\left(\mathrm{C}_{19} \mathrm{H}_{19} \mathrm{FN}_{3} \mathrm{O}^{+}\right)$and $\mathrm{D}_{5}\left(\mathrm{C}_{15} \mathrm{H}_{10} \mathrm{FN}_{2} \mathrm{O}^{+}\right)$of compound 5 by 14 amu, which indicated that compound $\mathbf{1}$ had an additional methylene moiety than that group of compound 5. According to the LC-MS spectral data, compound 1 was presumed to be $N$-(1-amino3,3-dimethyl-1-oxobutan-2-yl)-1-benzyl-1 $H$-indazole-3carboxamide. The fragment ions at $\mathrm{m} / \mathrm{z} 91,235$ and 320 of compound $\mathbf{1}$ in the GC-MS spectrum supported the presumed structure of compound $\mathbf{1}$ (Fig. 6a).

The structure of compound $\mathbf{1}$ was further elucidated by NMR analysis. The NMR spectra of this compound suggested the presence of two amide carbonyl groups $\left[\delta_{\mathrm{C}}\right.$ $160.9, \delta_{\mathrm{H}} 7.60(1-\mathrm{CONH})$ and $\delta_{\mathrm{C}} 171.7, \delta_{\mathrm{H}} 7.72$ and 7.26 $\left(1^{\prime \prime \prime}-\mathrm{CONH}_{2}\right)$ ] as shown in Table 2 . The analyses by ${ }^{1} \mathrm{H}$ and ${ }^{13} \mathrm{C}$ NMR, DEPT, HH COSY, HSQC and HMBC spectra of compound 1 revealed the presence of a 1-benzyl- $1 H$-indazole moiety (positions $3^{\prime}$ to $7^{\prime}$ a and positions $1^{\prime \prime}$ to $7^{\prime \prime}$ ) and an $\mathrm{N}$-(1-amino-3,3-dimethyl-1-oxobutan-2-yl)-carboxamide moiety (positions 1, 1-CONH, and $1^{\prime \prime \prime}-\mathrm{CONH}_{2}$, and positions $\left.1^{\prime \prime \prime}-6^{\prime \prime \prime}\right)$. Unfortunately, no HMBC correlation between the two moieties was observed. However, the chemical shifts of corresponding carbons of compound 1 [ $\delta_{\mathrm{C}} 160.9(\mathrm{C}-1), 136.9\left(\mathrm{C}-3^{\prime}\right), 122.2\left(\mathrm{C}-3^{\prime} \mathrm{a}\right), 121.7\left(\mathrm{C}-4^{\prime}\right)$, $122.7\left({\mathrm{C}-5^{\prime}}^{\prime}\right), 127.0\left(\mathrm{C}-6^{\prime}\right), 110.7\left(\mathrm{C}-7^{\prime}\right), 140.7\left(\mathrm{C}-7^{\prime} \mathrm{a}\right), 52.4$ $\left(\mathrm{C}-1^{\prime \prime}\right)$, and $\left.171.7\left(\mathrm{C}-1^{\prime \prime \prime}\right)\right]$ were similar to those of ABFUBINACA $\left[\delta_{\mathrm{C}} 161.2(\mathrm{C}-1), 137.1\left(\mathrm{C}-3^{\prime}\right), 122.3\left(\mathrm{C}-3^{\prime} \mathrm{a}\right)\right.$, $121.8\left(\mathrm{C}-4^{\prime}\right), 122.8\left({\mathrm{C}-5^{\prime}}^{\prime}\right), 127.0\left(\mathrm{C}-6^{\prime}\right), 110.6\left(\mathrm{C}-7^{\prime}\right), 140.6$ $\left(\mathrm{C}-7^{\prime} \mathrm{a}\right), 51.6\left(\mathrm{C}-1^{\prime \prime}\right)$, and $\left.172.6\left(\mathrm{C}-1^{\prime \prime \prime}\right)\right]$ (Table 2). This result suggested that carboxamide carbon $\left(\mathrm{C}-1, \delta_{\mathrm{C}} 160.9\right)$ in the $\mathrm{N}$-(1-amino-3,3-dimethyl-1-oxobutan-2-yl)-carboxamide moiety was attached to the carbon at the $3^{\prime}$-position $\left(\delta_{\mathrm{C}} 136.9\right)$ of the 1-benzyl-1H-indazole moiety as ABFUBINACA [9].

Finally, on the basis of mass spectra and NMR data as shown above, the structure of compound $\mathbf{1}$ was determined as an AB-FUBINACA analog [IUPAC: $N$-(1-amino-3,3dimethyl-1-oxobutan-2-yl)-1-benzyl- $1 H$-indazole-3-carboxamide] and named ADB-BINACA (Fig. 1). Compound 1 has been reported to have an affinity for $\mathrm{CB}_{1}$ receptor [10], 

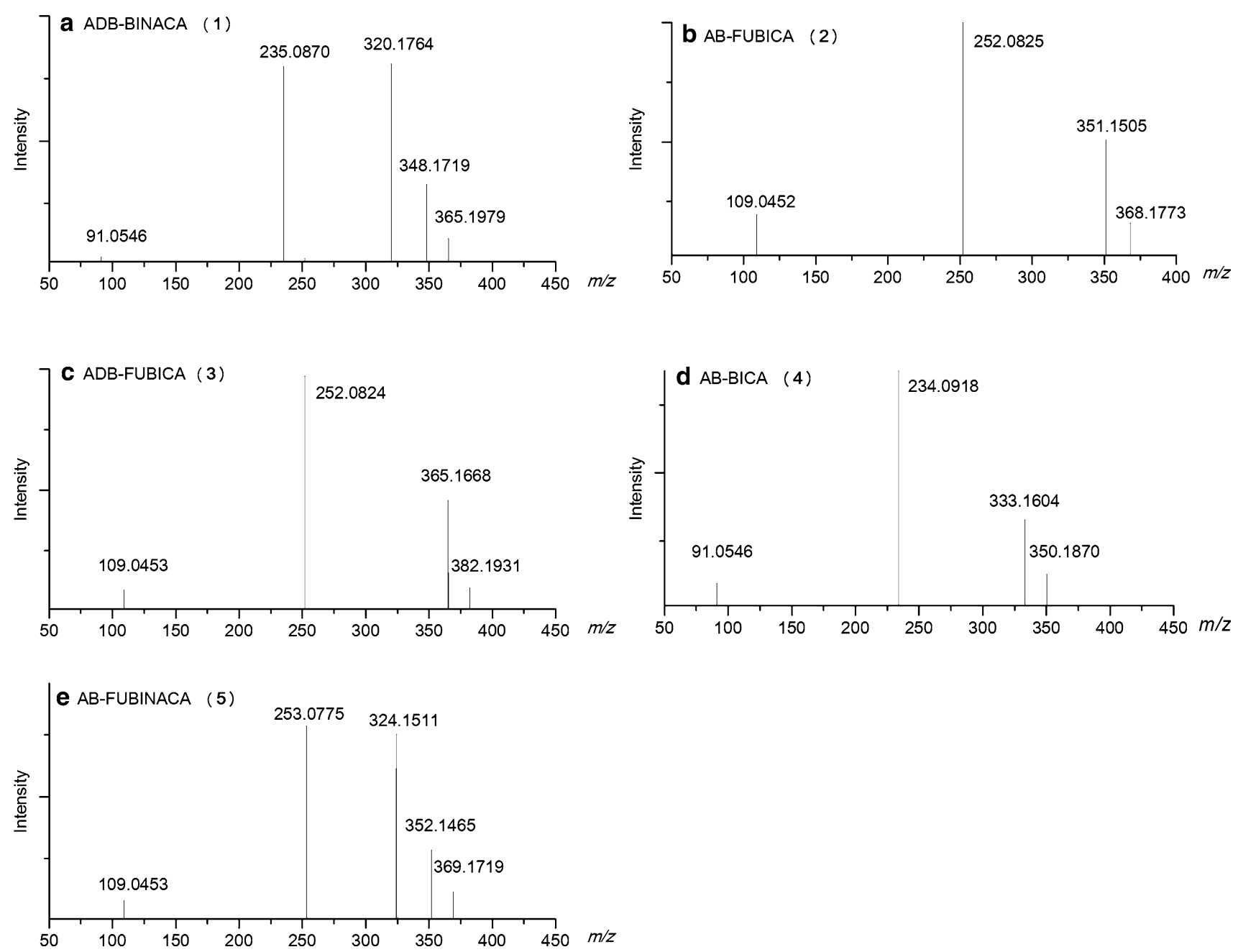

Fig. 3 Spectra of product ion spectra of compounds 1-5 obtained by LC-HR-MS in the tandem (MS/MS) mode

but this is the first report in which compound $\mathbf{1}$ has been detected in an illegal product.

\section{Identification of compounds 2 and 3}

The accurate mass spectra of compounds $\mathbf{2}$ and $\mathbf{3}$ were measured by LC-HR-MS(/MS) in the positive mode. The ion peak observed at $m / z 368.1773\left(\mathrm{~A}_{2}\right)$ and $382.1931\left(\mathrm{~A}_{3}\right)$ (Table 1) suggested that the protonated molecular formulae of these two compounds were $\mathrm{C}_{21} \mathrm{H}_{23} \mathrm{FN}_{3} \mathrm{O}_{2}{ }^{+}$(calcd. 368.1769) and $\mathrm{C}_{22} \mathrm{H}_{25} \mathrm{FN}_{3} \mathrm{O}_{2}{ }^{+}$(calcd. 382.1925), respectively.

Compound 2 was presumed to be $N$-(1-amino-3-methyl1-oxobutan-2-yl)-1-(4-fluorobenzyl)-1 $H$-indole-3-carboxamide based on the product ion/fragment patterns of the LC-HR-MS(/MS) analysis (Figs. 2b, 3b) and GC-MS analysis (Fig. 6b). The observed product ions at $m / z 109.0452\left(\mathrm{E}_{2}\right), 252.0825\left(\mathrm{D}_{2}\right)$ and $351.1505\left(\mathrm{~B}_{2}\right)$ of compound 2 (Fig. 3b) were similar to those of compound 5 (AB-FUBINACA) (Fig. 3e) obtained by LC-HR-MS/MS analysis. The product ion at $m / z 109.0452\left(\mathrm{E}_{2}\right)$ (predicted chemical formula: $\mathrm{C}_{7} \mathrm{H}_{6} \mathrm{~F}^{+}$) indicated the presence of a fluorobenzyl moiety. By comparing the product ion at $m / z 252.0825\left(\mathrm{D}_{2}\right)$ (predicted chemical formula: $\mathrm{C}_{16} \mathrm{H}_{11-}$ $\mathrm{FNO}^{+}$) in compound 2 (Fig. $3 \mathrm{~b}$ ) with the product ion at $m / z 253.0775\left(\mathrm{D}_{5}\right)$ (predicted chemical formula: $\mathrm{C}_{15} \mathrm{H}_{10}$ $\mathrm{FN}_{2} \mathrm{O}^{+}$) in compound $\mathbf{5}$, one can predicted compound $\mathbf{2}$ has an 1-pentyl-1H-indole-3-carbonyl moiety. The mass difference value between product ions at $\mathrm{m} / z 252.0825\left(\mathrm{D}_{2}\right)$ and $109.0452\left(\mathrm{E}_{2}\right)$ also indicated the indole-carbonyl moiety by comparing of the product ion pattern of a known synthetic cannabinoid that has the same moiety, such as ADBICA [7].

The structure of compound $\mathbf{2}$ was further elucidated by GC-MS and NMR analyses. The fragment ions at $\mathrm{m} / \mathrm{z} .109$, 252 and 323 of compound 2 by GC-MS analysis (Fig. 6b) and the observed ${ }^{1} \mathrm{H}$ and ${ }^{13} \mathrm{C}$ NMR, DEPT, HH COSY, HSQC, and HMBC spectra for compound $\mathbf{2}$ suggested the presence of a 1-(4-fluorobenzyl)- $1 H$-indole moiety (positions $2^{\prime}$ to $7^{\prime} \mathrm{a}$ and positions $\left.1^{\prime \prime}-7^{\prime \prime}\right)$ and an $N$-(1-amino-3- 
Table 1 Accurate mass numbers of the protonated molecular and predominant product ions, and their proposed chemical formulae obtained for compounds 1-5 measured by liquid chromatography-high-resolution mass spectrometry (/mass spectrometry)

\begin{tabular}{|c|c|c|c|c|c|c|}
\hline Compound & $\mathrm{RT}(\min )^{\mathrm{a}}$ & Fragment & Chemical formula & Calculated mass & Experimental mass & Error (ppm) \\
\hline \multirow[t]{5}{*}{ (ADB-BINACA, 1) } & \multirow[t]{5}{*}{5.56} & $\mathrm{~A}_{1}$ & $\mathrm{C}_{21} \mathrm{H}_{25} \mathrm{~N}_{4} \mathrm{O}_{2}^{+}$ & 365.1972 & 365.1979 & 1.9 \\
\hline & & $\mathrm{B}_{1}$ & $\mathrm{C}_{21} \mathrm{H}_{22} \mathrm{~N}_{3} \mathrm{O}_{2}^{+}$ & 348.1712 & 348.1719 & 2.0 \\
\hline & & $\mathrm{C}_{1}$ & $\mathrm{C}_{20} \mathrm{H}_{22} \mathrm{~N}_{3} \mathrm{O}^{+}$ & 320.1757 & 320.1764 & 2.2 \\
\hline & & $\mathrm{D}_{1}$ & $\mathrm{C}_{15} \mathrm{H}_{11} \mathrm{~N}_{2} \mathrm{O}^{+}$ & 235.0866 & 235.0870 & 1.7 \\
\hline & & $\mathrm{E}_{1}$ & $\mathrm{C}_{7} \mathrm{H}_{7}^{+}$ & 91.0542 & 91.0546 & 4.4 \\
\hline \multirow[t]{4}{*}{ (AB-FUBICA, 2) } & \multirow[t]{4}{*}{5.24} & $\mathrm{~A}_{2}$ & $\mathrm{C}_{21} \mathrm{H}_{23} \mathrm{FN}_{3} \mathrm{O}_{2}^{+}$ & 368.1769 & 368.1773 & 1.1 \\
\hline & & $\mathrm{B}_{2}$ & $\mathrm{C}_{21} \mathrm{H}_{20} \mathrm{FN}_{2} \mathrm{O}_{2}{ }^{+}$ & 351.1503 & 351.1505 & 0.6 \\
\hline & & $\mathrm{D}_{2}$ & $\mathrm{C}_{16} \mathrm{H}_{11} \mathrm{FNO}^{+}$ & 252.0819 & 252.0825 & 2.4 \\
\hline & & $\mathrm{E}_{2}$ & $\mathrm{C}_{7} \mathrm{H}_{6} \mathrm{~F}^{+}$ & 109.0448 & 109.0452 & 3.7 \\
\hline \multirow[t]{4}{*}{ (ADB-FUBICA, 3) } & \multirow[t]{4}{*}{5.46} & $\mathrm{~A}_{3}$ & $\mathrm{C}_{22} \mathrm{H}_{25} \mathrm{FN}_{3} \mathrm{O}_{2}^{+}$ & 382.1925 & 382.1931 & 1.6 \\
\hline & & $\mathrm{B}_{3}$ & $\mathrm{C}_{22} \mathrm{H}_{22} \mathrm{FN}_{2} \mathrm{O}_{2}^{+}$ & 365.1660 & 365.1668 & 2.2 \\
\hline & & $\mathrm{D}_{3}$ & $\mathrm{C}_{16} \mathrm{H}_{11} \mathrm{FNO}^{+}$ & 252.0819 & 252.0824 & 2.0 \\
\hline & & $\mathrm{E}_{3}$ & $\mathrm{C}_{7} \mathrm{H}_{6} \mathrm{~F}^{+}$ & 109.0448 & 109.0453 & 4.6 \\
\hline \multirow[t]{4}{*}{$(\mathrm{AB}-\mathrm{BICA}, \mathbf{4})$} & \multirow[t]{4}{*}{5.2} & $\mathrm{~A}_{4}$ & $\mathrm{C}_{21} \mathrm{H}_{24} \mathrm{~N}_{3} \mathrm{O}_{2}^{+}$ & 350.1863 & 350.1870 & 2.0 \\
\hline & & $\mathrm{B}_{4}$ & $\mathrm{C}_{21} \mathrm{H}_{21} \mathrm{~N}_{2} \mathrm{O}_{2}^{+}$ & 333.1598 & 333.1604 & 1.8 \\
\hline & & $\mathrm{D}_{4}$ & $\mathrm{C}_{16} \mathrm{H}_{12} \mathrm{NO}^{+}$ & 234.0913 & 234.0918 & 2.1 \\
\hline & & $\mathrm{E}_{4}$ & $\mathrm{C}_{7} \mathrm{H}_{7}^{+}$ & 91.0542 & 91.0546 & 4.4 \\
\hline \multirow[t]{5}{*}{ (AB-FUBINACA, 5) } & \multirow[t]{5}{*}{5.34} & $A_{5}$ & $\mathrm{C}_{20} \mathrm{H}_{22} \mathrm{FN}_{4} \mathrm{O}_{2}^{+}$ & 369.1721 & 369.1719 & -0.5 \\
\hline & & $\mathrm{B}_{5}$ & $\mathrm{C}_{20} \mathrm{H}_{19} \mathrm{FN}_{3} \mathrm{O}_{2}^{+}$ & 352.1461 & 352.1465 & 1.1 \\
\hline & & $\mathrm{C}_{5}$ & $\mathrm{C}_{19} \mathrm{H}_{19} \mathrm{FN}_{3} \mathrm{O}^{+}$ & 324.1507 & 324.1511 & 1.2 \\
\hline & & $\mathrm{D}_{5}$ & $\mathrm{C}_{15} \mathrm{H}_{10} \mathrm{FN}_{2} \mathrm{O}^{+}$ & 253.0772 & 253.0775 & 1.2 \\
\hline & & $\mathrm{E}_{5}$ & $\mathrm{C}_{7} \mathrm{H}_{7} \mathrm{~F}^{+}$ & 109.0448 & 109.0453 & 4.6 \\
\hline
\end{tabular}

${ }^{a} R T$ retention time

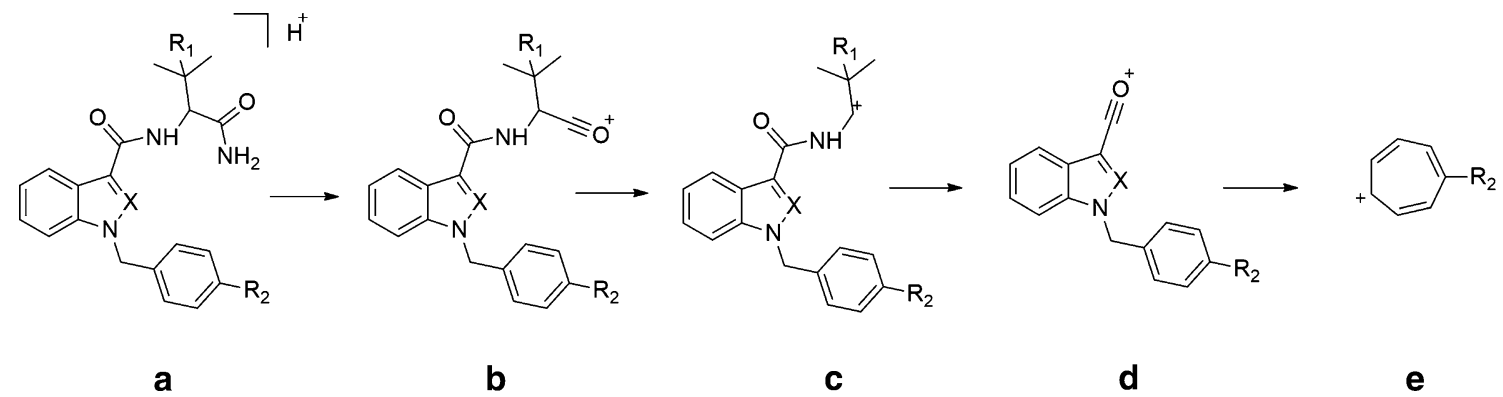

Fig. 4 Proposed fragmentation routes of protonated compounds $\mathbf{1}-\mathbf{5}$

methyl-1-oxobutan-2-yl)-carboxamide moiety (positions 1 , 1-CONH, and $1^{\prime \prime \prime}-\mathrm{CONH}_{2}$, and positions $\left.1^{\prime \prime \prime}-5^{\prime \prime \prime}\right)$ as shown in Table 3. The key connections of the two moieties were revealed by the HMBC correlations. Namely, the HMBC correlations from the amide proton $\left(1-\mathrm{CONH}, \delta_{\mathrm{H}} 7.57\right)$ and the indole proton $\left(\mathrm{H}-2^{\prime}, \delta_{\mathrm{H}} 8.35\right)$ to the carboxamide carbon atom $\left(\mathrm{C}-1, \delta_{\mathrm{C}} 163.9\right)$ suggested that the carboxamide carbon (C-1) in the $N$-(1-amino-3-methyl-1-oxobutan-2-yl)carboxamide moiety was attached to the carbon at the $3^{\prime}$ position of the 1-(4-fluorobenzyl)- $1 H$-indole moiety. Therefore, the structure of compound $\mathbf{2}$ was determined to be $N$-(1-amino-3-methyl-1-oxobutan-2-yl)-1-(4-fluorobenzyl)- $1 H$-indole-3-carboxamide (AB-FUBICA).

The ${ }^{13} \mathrm{C}$ NMR spectrum of compound 3 was very similar to that of compound $\mathbf{2}$ except for a dimethylpropyl moiety (position $2^{\prime \prime \prime}-6^{\prime \prime \prime}$ ) as shown in Table 4 . The difference between the molecular formulae of compound 3 $\left(\mathrm{C}_{22} \mathrm{H}_{24} \mathrm{FN}_{3} \mathrm{O}_{2}\right)$ and compound $2\left(\mathrm{C}_{21} \mathrm{H}_{22} \mathrm{FN}_{3} \mathrm{O}_{2}\right)$ is an additional $\mathrm{CH}_{2}$. The observed 1D and 2D NMR spectra of compound 3 suggested the presence of 1-(4-fluorobenzyl)$1 \mathrm{H}$-indole and $\mathrm{N}$-(1-amino-3,3-dimethyl-1-oxobutan-2yl)-carboxamide moieties. That is, compound $\mathbf{3}$ may have 

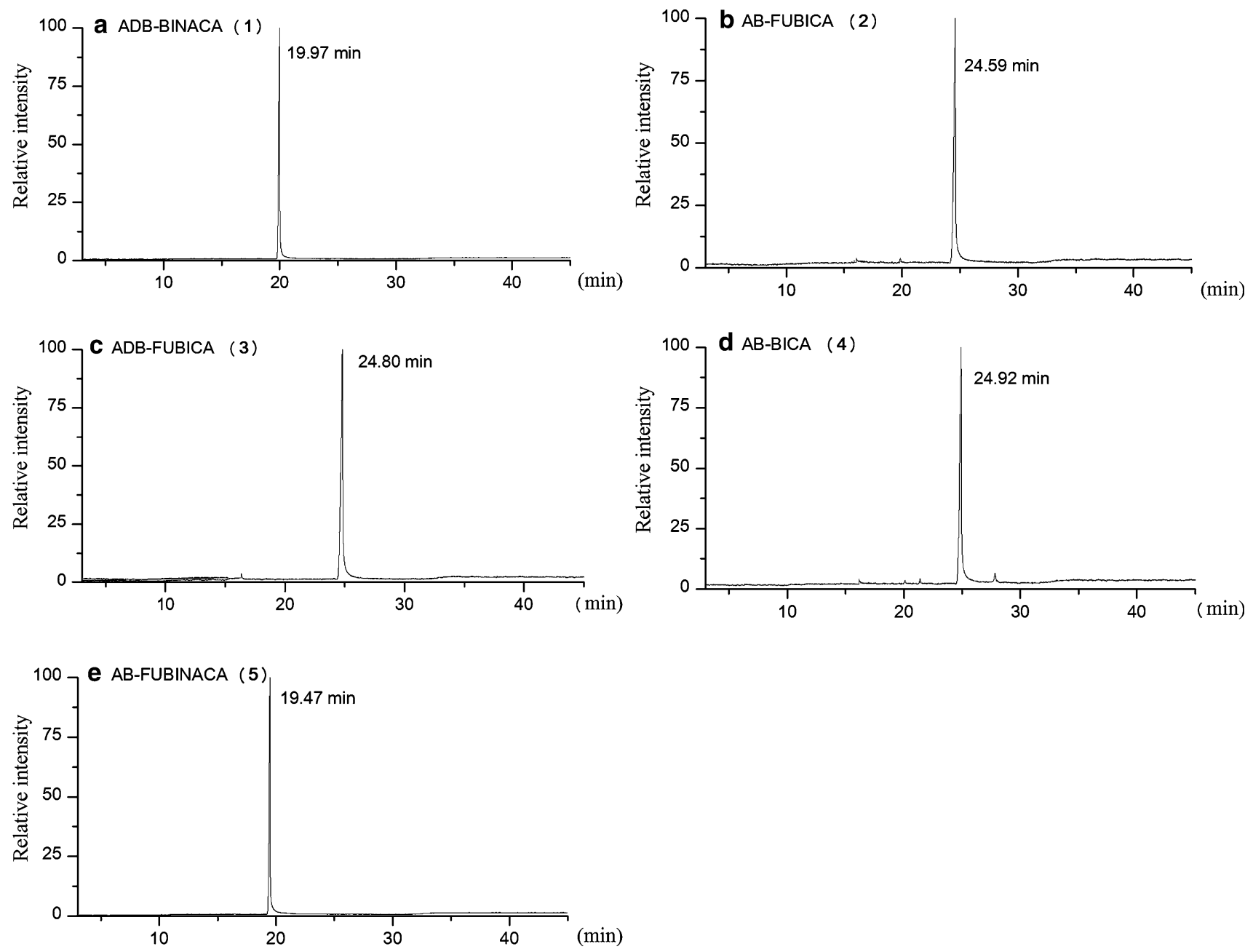

Fig. 5 Total ion current chromatogram for samples containing compounds 1-5 obtained by gas chromatography-electron ionization-mass spectrometry (GC-EI-MS)

an additional methyl group at the $3^{\prime \prime \prime}$-position in the structure of compound 2 . Therefore, the structure of compound $\mathbf{3}$ was deduced to be $N$-(1-amino-3,3-dimethyl1-oxobutan-2-yl)-1-(4-fluorobenzyl)-1 $H$-indole-3-carboxamide (ADB-FUBICA). In addition, the product ions at $m / z 109.0453\left(\mathrm{E}_{3}\right), 252.0824\left(\mathrm{D}_{3}\right)$, and $365.1668\left(\mathrm{~B}_{3}\right)$ obtained by the LC-HR-MS/MS analysis (Fig. 3c), together with the fragment ions at $\mathrm{m} / \mathrm{z}, 109,252$ and 337 obtained by the GC-MS analysis (Fig. 6c) supported the presumed structure.

This is the first case in which compounds $\mathbf{2}$ and $\mathbf{3}$ has been detected in illegal products. Compounds $\mathbf{2}$ and $\mathbf{3}$ have been reported to have an affinity for $\mathrm{CB}_{1}$ and $\mathrm{CB}_{2}$ receptors [7].

\section{Identification of compound 4}

LC-HR-MS analysis of compound $\mathbf{4}$ gave an ion peak at $\mathrm{m} / \mathrm{z}$ 350.1876, suggesting that the protonated molecular formula of compound was $\mathrm{C}_{21} \mathrm{H}_{24} \mathrm{~N}_{3} \mathrm{O}_{2}{ }^{+}$(calcd.
$350.1863)$. Compound 4 was presumed to be $N$-(1-amino3-methyl-1-oxobutan-2-yl)-1-benzyl-1 $H$-indole-3-carboxamide based on the product ion/fragment patterns of the LC-HR-MS(/MS) analysis (Fig. 3d) and GC-MS analysis (Fig. 6d). The LC-HR-MS/MS profile of compound $\mathbf{4}$ was very similar to that of compound $\mathbf{2}$ (Fig. $3 \mathrm{~b}$ ). The product ion at $\mathrm{m} / \mathrm{z} 91.0546\left(\mathrm{E}_{4}\right)$ (predicted chemical formula: $\mathrm{C}_{7} \mathrm{H}_{7}{ }^{+}$) indicated the presence of an un-substituted benzyl moiety. In addition, the fragment ions of compound $\mathbf{4}$ at $\mathrm{m} / \mathrm{z} 349,305,234,91$ in GC-MS spectrum were all lower than those of compound $2(367,323,252,109)$ by $18 \mathrm{amu}$, which indicated the difference between compounds $\mathbf{4}$ and $\mathbf{2}$ was a single fluoro-substitution.

The structure of compound $\mathbf{4}$ was further elucidated by NMR analysis. The ${ }^{13} \mathrm{C}$ NMR spectrum of compound 4 was very similar to that of compound $\mathbf{2}$ except for a benzyl moiety (positions $2^{\prime \prime}$ to $7^{\prime \prime}$ ) as shown in Table 5. The difference between the molecular formulae of compound 4 $\left(\mathrm{C}_{21} \mathrm{H}_{23} \mathrm{~N}_{3} \mathrm{O}_{2}\right)$ and compound $2\left(\mathrm{C}_{21} \mathrm{H}_{22} \mathrm{FN}_{3} \mathrm{O}_{2}\right)$ is an 

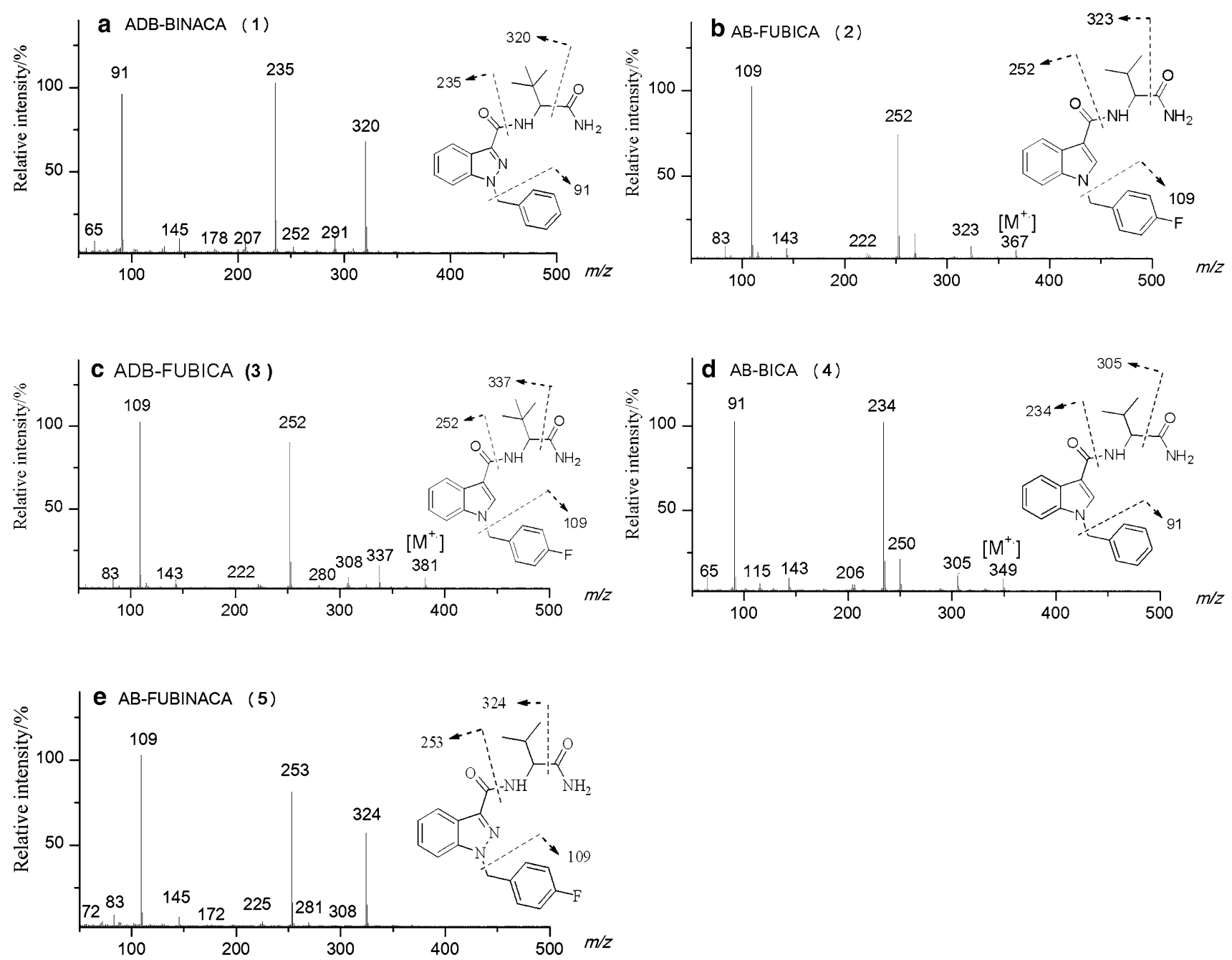

Fig. 6 Mass spectra of compounds 1-5 obtained by GC-EI-MS together with their probable fragmentation modes

additional hydrogen atom in the place of the absent fluorine atom. The observed ${ }^{1} \mathrm{H}$ and ${ }^{13} \mathrm{C}$ NMR, DEPT, HH COSY, HSQC, and HMBC spectra for compound 4 suggested the presence of 1-benzyl-1H-indole and $\mathrm{N}$-(1-amino-3-methyl1-oxobutan-2-yl)-carboxamide moieties. Compound 4 may have a benzyl group instead of the 4-fluorobenzyl group in the structure of compound 2.

Finally, on the basis of mass spectral and NMR data as shown above, the structure of compound $\mathbf{4}$ was finally determined as an AB-FUBICA analog [IUPAC: $N$-(1amino-3-methyl-1-oxobutan-2-yl)-1-benzyl-1H-indole-3carboxamide], and named AB-BICA (Fig. 1).

This is the first report in which compound $\mathbf{4}$ has been reported and detected. Compound $\mathbf{4}$ is a novel cannabimimetic substance; its chemical and pharmacological data have not been reported previously. However, para-F-substituted benzyl indole analog of compound $\mathbf{4}$ has been reported as a cannabinoid $\mathrm{CB}_{1}$ and $\mathrm{CB}_{2}$ receptor modulator
[7]. Therefore, it is assumed that compound $\mathbf{4}$ may have a similar cannabimimetic activity.

\section{Conclusions}

In this study, four new synthetic cannabimimetic indazole and indole derivatives, ADB-BINACA (1), AB-FUBICA (2), ADB-FUBICA (3), and AB-BICA (4) have been identified as NPSs in illegal products seized in a clandestine laboratory. Chemical structures of these compounds were elucidated by LC-HR-MS/MS, GC-MS and NMR spectroscopy. Compound $\mathbf{4}$ has neither been reported as a synthetic compound in the literature nor as an adulterant in dubious products, and was an entirely novel compound. Compounds 1-3 have been reported to have potent binding affinity for cannabinoid $\mathrm{CB}_{1}$ and $\mathrm{CB}_{2}$ receptors, but have not been detected in illegal products. Because of the limited pharmacological and toxicological information for 
Table 2 Nuclear magnetic resonance (NMR) data for compound $\mathbf{1}$

\begin{tabular}{|c|c|c|c|c|}
\hline \multirow[t]{2}{*}{ No. } & \multicolumn{3}{|c|}{ Compound $\mathbf{1}^{\mathrm{a}}$} & \multirow{2}{*}{$\begin{array}{l}\text { AB-FUBINACA }{ }^{\mathrm{b}} \\
{ }^{13} \mathrm{C}\end{array}$} \\
\hline & ${ }^{13} \mathrm{C}$ & ${ }^{1} \mathrm{H}$ & $\mathrm{HMBC}^{\mathrm{c}}$ & \\
\hline 1 & 160.9 & - & - & 161.2 \\
\hline $3^{\prime}$ & 136.9 & - & - & 137.1 \\
\hline $3^{\prime} \mathrm{a}$ & 122.2 & - & - & 122.3 \\
\hline $4^{\prime}$ & 121.7 & $8.19,1 \mathrm{H}$, d-like, $J=8.4 \mathrm{~Hz}$ & $3^{\prime}, 6^{\prime}, 7^{\prime} \mathrm{a}$ & 121.8 \\
\hline $5^{\prime}$ & 122.7 & $7.29,1 \mathrm{H}, \mathrm{m}$, overlapped & $3^{\prime} \mathrm{a}, 7^{\prime}$ & 122.8 \\
\hline $6^{\prime}$ & 127.0 & $7.45,1 \mathrm{H}, \mathrm{ddd}, J=8.4,7.0,1.2 \mathrm{~Hz}$ & $4^{\prime}, 7^{\prime} \mathrm{a}$ & 127.0 \\
\hline $7^{\prime}$ & 110.7 & $7.77,1 \mathrm{H}, \mathrm{d}$-like, $J=8.8 \mathrm{~Hz}$ & $3^{\prime} \mathrm{a}, 5^{\prime}$ & 110.6 \\
\hline $7^{\prime} \mathrm{a}$ & 140.7 & - & - & 140.6 \\
\hline $1^{\prime \prime}$ & 52.4 & $5.79,2 \mathrm{H}, \mathrm{s}$ & $7^{\prime} \mathrm{a}, 2^{\prime \prime}, 3^{\prime \prime} / 7^{\prime \prime}$ & 51.6 \\
\hline $2^{\prime \prime}$ & 136.7 & - & - & $133.0, \mathrm{~d}, J=2.9 \mathrm{~Hz}$ \\
\hline $3^{\prime \prime} / 7^{\prime \prime}$ & 127.2 & $7.26,2 \mathrm{H}, \mathrm{m}$, overlapped & $1^{\prime \prime}, 5^{\prime \prime}$ & $129.5, \mathrm{~d}, J=8.7 \mathrm{~Hz}$ \\
\hline $4^{\prime \prime} / 6^{\prime \prime}$ & 128.7 & $7.32,2 \mathrm{H}, \mathrm{m}$, overlapped & $2^{\prime \prime}, 5^{\prime \prime}$ & $115.5, \mathrm{~d}, J=21.7 \mathrm{~Hz}$ \\
\hline $5^{\prime \prime}$ & 127.7 & $7.27,1 \mathrm{H}, \mathrm{m}$, overlapped & $3^{\prime \prime} / 7^{\prime \prime}$ & $161.6, \mathrm{~d}, J=242.8 \mathrm{~Hz}$ \\
\hline $1^{\prime \prime \prime}$ & 171.7 & - & - & 172.6 \\
\hline $2^{\prime \prime \prime}$ & 58.7 & $4.48,1 \mathrm{H}, \mathrm{d}, J=9.6 \mathrm{~Hz}$ & $1,1^{\prime \prime \prime}, 3^{\prime \prime \prime}, 4^{\prime \prime \prime} / 5^{\prime \prime \prime} / 6^{\prime \prime \prime}$ & 56.9 \\
\hline $3^{\prime \prime \prime}$ & 34.5 & - & - & 31.2 \\
\hline $4^{\prime \prime \prime} / 5^{\prime \prime \prime} / 6^{\prime \prime \prime}$ & 26.6 & $1.00,9 \mathrm{H}, \mathrm{s}$ & $2^{\prime \prime \prime}, 3^{\prime \prime \prime}$ & $19.4,18.1$ \\
\hline $1-\mathrm{CONH}$ & - & $7.60,1 \mathrm{H}, \mathrm{d}, J=10.0 \mathrm{~Hz}$ & $1,1^{\prime \prime \prime}, 2^{\prime \prime \prime}$ & - \\
\hline \multirow[t]{2}{*}{$1^{\prime \prime \prime}-\mathrm{CONH}_{2}$} & - & $7.72,1 \mathrm{H}, \mathrm{brs}$ & $1^{\prime \prime \prime}$ & - \\
\hline & - & $7.26,1 \mathrm{H}$, brs, overlapped & $1^{\prime \prime \prime}, 2^{\prime \prime \prime}$ & - \\
\hline
\end{tabular}

${ }^{\text {a }}$ Recorded in dimethyl sulfoxide (DMSO- $\left.d_{6}\right)$ at $400 \mathrm{MHz}\left({ }^{1} \mathrm{H}\right)$ and $100 \mathrm{MHz}\left({ }^{13} \mathrm{C}\right)$, respectively; data in $\delta \mathrm{ppm}$

${ }^{\mathrm{b}}$ Ref [9], recorded in DMSO- $d_{6}$ at $150 \mathrm{MHz}\left({ }^{13} \mathrm{C}\right)$, respectively; data in $\delta \mathrm{ppm}$

${ }^{c} H M B C$ heteronuclear multiple-bond correlation spectroscopy. $J=8 \mathrm{~Hz}$; the proton signal correlated with the indicated carbons

Table 3 NMR data for compound 2

\begin{tabular}{|c|c|c|c|}
\hline No. & ${ }^{13} \mathrm{C}$ & ${ }^{1} \mathrm{H}$ & HMBC \\
\hline 1 & 163.9 & - & - \\
\hline $2^{\prime}$ & 131.6 & $8.35,1 \mathrm{H}, \mathrm{s}$ & $1,3^{\prime}, 3^{\prime} \mathrm{a}, 7^{\prime} \mathrm{a}, 1^{\prime \prime}$ \\
\hline $3^{\prime}$ & 110.0 & - & - \\
\hline $3^{\prime} \mathrm{a}$ & 126.6 & - & - \\
\hline $4^{\prime}$ & 121.1 & $8.11,1 \mathrm{H}, \mathrm{m}$ & $3^{\prime}, 6^{\prime}, 7^{\prime} \mathrm{a}$ \\
\hline $5^{\prime}$ & 120.8 & $7.15,1 \mathrm{H}, \mathrm{m}$, overlapped & $3^{\prime} \mathrm{a}, 7^{\prime}$ \\
\hline $6^{\prime}$ & 122.1 & $7.17,1 \mathrm{H}, \mathrm{m}$, overlapped & $4^{\prime}, 7^{\prime} \mathrm{a}$ \\
\hline $7^{\prime}$ & 110.6 & $7.53,1 \mathrm{H}, \mathrm{m}$, overlapped & $3^{\prime} \mathrm{a}, 5^{\prime}$ \\
\hline $7^{\prime} \mathrm{a}$ & 136.0 & - & - \\
\hline $1^{\prime \prime}$ & 48.7 & $5.45,2 \mathrm{H}, \mathrm{m}$ & $2^{\prime}, 7^{\prime} \mathrm{a}, 2^{\prime \prime}, 3^{\prime \prime} / 7^{\prime \prime}$ \\
\hline $2^{\prime \prime}$ & $133.7, \mathrm{~d}, J=3.0 \mathrm{~Hz}$ & - & - \\
\hline $3^{\prime \prime} / 7^{\prime \prime}$ & $129.3, \mathrm{~d}, J=8.4 \mathrm{~Hz}$ & $7.33,2 \mathrm{H}, \mathrm{m}$ & $1^{\prime \prime}, 4^{\prime \prime} / 6^{\prime \prime}, 5^{\prime \prime}$ \\
\hline $4^{\prime \prime} / 6^{\prime \prime}$ & $115.4, \mathrm{~d}, J=21.2 \mathrm{~Hz}$ & $7.16,2 \mathrm{H}, \mathrm{m}$, overlapped & $2^{\prime \prime}, 3^{\prime \prime} / 7^{\prime \prime}, 5^{\prime \prime}$ \\
\hline $5^{\prime \prime}$ & $161.5, \mathrm{~d}, J=242.0 \mathrm{~Hz}$ & - & - \\
\hline $1^{\prime \prime \prime}$ & 173.5 & - & - \\
\hline $2^{\prime \prime \prime}$ & 57.4 & $4.36,1 \mathrm{H}, \mathrm{dd}, J=8.8,7.2 \mathrm{~Hz}$ & $1,1^{\prime \prime \prime}, 3^{\prime \prime \prime}, 4^{\prime \prime \prime}, 5^{\prime \prime \prime}$ \\
\hline $3^{\prime \prime \prime}$ & 30.4 & $2.09,1 \mathrm{H}, \mathrm{m}$ & $2^{\prime \prime \prime}, 4^{\prime \prime \prime}, 5^{\prime \prime \prime}$ \\
\hline $4^{\prime \prime \prime}$ & 19.5 & $0.95,3 \mathrm{H}, \mathrm{d}, J=6.4 \mathrm{~Hz}$ & $2^{\prime \prime \prime}, 3^{\prime \prime \prime}, 5^{\prime \prime \prime}$ \\
\hline $5^{\prime \prime \prime}$ & 18.5 & $0.94,3 \mathrm{H}, \mathrm{d}, J=6.8 \mathrm{~Hz}$ & $2^{\prime \prime \prime}, 3^{\prime \prime \prime}, 4^{\prime \prime \prime}$ \\
\hline 1-CONH & - & $7.57,1 \mathrm{H}, \mathrm{d}, J=8.8 \mathrm{~Hz}$, overlapped & $1,2^{\prime \prime \prime}$ \\
\hline \multirow[t]{2}{*}{$1^{\prime \prime \prime}-\mathrm{CONH}_{2}$} & - & $7.48,1 \mathrm{H}, \mathrm{brs}$ & $1^{\prime \prime \prime}$ \\
\hline & - & $7.07,1 \mathrm{H}, \mathrm{brs}$ & $1^{\prime \prime \prime}, 2^{\prime \prime \prime}$ \\
\hline
\end{tabular}

Recorded under the same conditions as specified in Table 2 
Table 4 NMR data for compound $\mathbf{3}$

\begin{tabular}{llll}
\hline No. & ${ }^{13} \mathrm{C}$ & ${ }^{1} \mathrm{H}$ & $\mathrm{HMBC}$ \\
\hline 1 & 163.7 & - & - \\
$2^{\prime}$ & 131.9 & $8.42,1 \mathrm{H}, \mathrm{s}$ & $1,3^{\prime}, 3^{\prime} \mathrm{a}, 7^{\prime} \mathrm{a}, 1^{\prime \prime}$ \\
$3^{\prime}$ & 110.0 & - & - \\
$3^{\prime} \mathrm{a}$ & 126.5 & - & - \\
$4^{\prime}$ & 120.9 & $8.08,1 \mathrm{H}, \mathrm{m}$ & $3^{\prime}, 6^{\prime}, 7^{\prime} \mathrm{a}$ \\
$5^{\prime}$ & 120.8 & $7.16,1 \mathrm{H}, \mathrm{m}$, overlapped & $3^{\prime} \mathrm{a}, 7^{\prime}$ \\
$6^{\prime}$ & 122.1 & $7.17,1 \mathrm{H}, \mathrm{m}$, overlapped & $4^{\prime}, 7^{\prime} \mathrm{a}$ \\
$7^{\prime}$ & 110.8 & $7.53,1 \mathrm{H}, \mathrm{m}$ & $3^{\prime} \mathrm{a}, 5^{\prime}$ \\
$7^{\prime} \mathrm{a}$ & 136.0 & - & - \\
$1^{\prime \prime}$ & 48.7 & $5.46,2 \mathrm{H}, \mathrm{m}$ & $2^{\prime}, 7^{\prime} \mathrm{a}, 2^{\prime \prime}, 3^{\prime \prime} / 7^{\prime \prime}$ \\
$2^{\prime \prime}$ & $133.7, \mathrm{~d}, J=3.0 \mathrm{~Hz}$ & - & - \\
$3^{\prime \prime} / 7^{\prime \prime}$ & $129.3, \mathrm{~d}, J=8.2 \mathrm{~Hz}$ & $7.34,2 \mathrm{H}, \mathrm{m}$ & $1^{\prime \prime}, 4^{\prime \prime} / 6^{\prime \prime}, 5^{\prime \prime}$ \\
$4^{\prime \prime} / 6^{\prime \prime}$ & $115.4, \mathrm{~d}, J=21.3 \mathrm{~Hz}$ & $7.16,2 \mathrm{H}, \mathrm{m}$, overlapped & $2^{\prime \prime}, 3^{\prime \prime} / 7^{\prime \prime}, 5^{\prime \prime}$ \\
$5^{\prime \prime}$ & $161.5, \mathrm{~d}, J=242.0 \mathrm{~Hz}$ & - & - \\
$1^{\prime \prime \prime}$ & 172.5 & - & - \\
$2^{\prime \prime \prime}$ & 59.2 & $4.48,1 \mathrm{H}, \mathrm{d}, J=9.6 \mathrm{~Hz}$ & $1,1^{\prime \prime \prime}, 3^{\prime \prime \prime}, 4^{\prime \prime \prime} / 5^{\prime \prime \prime} / 6^{\prime \prime \prime}$ \\
$3^{\prime \prime \prime}$ & 34.1 & - & - \\
$4^{\prime \prime \prime} / 5^{\prime \prime \prime} / 6^{\prime \prime \prime}$ & 26.9 & $1.02,9 \mathrm{H}, \mathrm{s}$ & $2^{\prime \prime \prime}, 3^{\prime \prime \prime}$ \\
$1^{-C O N H}$ & - & $7.25,1 \mathrm{H}, \mathrm{d}, J=9.2 \mathrm{~Hz}$ & $1,1^{\prime \prime \prime}, 2^{\prime \prime \prime}$ \\
$1^{\prime \prime \prime}-\mathrm{CONH}{ }_{2}$ & - & $7.56,1 \mathrm{H}, \mathrm{brs}$ & $1^{\prime \prime \prime}$ \\
& - & $7.11,1 \mathrm{H}, \mathrm{brs}$ & $1^{\prime \prime \prime}, 2^{\prime \prime \prime}$ \\
\hline & & $796 \mathrm{~s} 2$ &
\end{tabular}

Recorded under the same conditions as specified in Table 2

Recorded under the same conditions as specified in Table 2

\begin{tabular}{llll}
\hline No. & ${ }^{13} \mathrm{C}$ & ${ }^{1} \mathrm{H}$ & HMBC \\
\hline 1 & 164.0 & - & - \\
$2^{\prime}$ & 131.7 & $8.38,1 \mathrm{H}, \mathrm{s}$ & $1,3^{\prime}, 3^{\prime} \mathrm{a}, 7^{\prime} \mathrm{a}, 1^{\prime \prime}$ \\
$3^{\prime}$ & 109.9 & - & - \\
$3^{\prime} \mathrm{a}$ & 126.6 & - & - \\
$4^{\prime}$ & 121.1 & $8.12,1 \mathrm{H}, \mathrm{m}$ & $3^{\prime}, 6^{\prime}, 7^{\prime} \mathrm{a}$ \\
$5^{\prime}$ & 120.8 & $7.14,1 \mathrm{H}, \mathrm{m}$, overlapped & $3^{\prime} \mathrm{a}, 7^{\prime}$ \\
$6^{\prime}$ & 122.1 & $7.16,1 \mathrm{H}, \mathrm{m}$, overlapped & $4^{\prime}, 7^{\prime} \mathrm{a}$ \\
$7^{\prime}$ & 110.7 & $7.52,1 \mathrm{H}, \mathrm{m}$, overlapped & $3^{\prime} \mathrm{a}, 5^{\prime}$ \\
$7^{\prime} \mathrm{a}$ & 136.1 & - & - \\
$1^{\prime \prime}$ & 49.5 & $5.46,2 \mathrm{H}, \mathrm{m}$ & $2^{\prime}, 7^{\prime} \mathrm{a}, 2^{\prime \prime}, 3^{\prime \prime} / 7^{\prime \prime}$ \\
$2^{\prime \prime}$ & 137.5 & - & - \\
$3^{\prime \prime} / 7^{\prime \prime}$ & 127.2 & $7.27,2 \mathrm{H}, \mathrm{m}$, overlapped & $1^{\prime \prime}, 5^{\prime \prime}$ \\
$4^{\prime \prime} / 6^{\prime \prime}$ & 128.6 & $7.33,2 \mathrm{H}, \mathrm{m}$ & $2^{\prime \prime}, 5^{\prime \prime}$ \\
$5^{\prime \prime}$ & 127.6 & $7.27,1 \mathrm{H}, \mathrm{m}$, overlapped & $3^{\prime \prime} / 7^{\prime \prime}$ \\
$1^{\prime \prime \prime}$ & 173.5 & - & - \\
$2^{\prime \prime \prime}$ & 57.5 & $4.36,1 \mathrm{H}, \mathrm{dd}, J=8.8,7.2 \mathrm{~Hz}$ & $1,1^{\prime \prime \prime}, 3^{\prime \prime \prime}, 4^{\prime \prime \prime}, 5^{\prime \prime \prime}$ \\
$3^{\prime \prime \prime}$ & 30.4 & $2.09,1 \mathrm{H}, \mathrm{m}$ & $1^{\prime \prime \prime}, 2^{\prime \prime \prime}, 4^{\prime \prime \prime}, 5^{\prime \prime \prime}$ \\
$4^{\prime \prime \prime}$ & 19.5 & $0.95,3 \mathrm{H}, \mathrm{d}, J=6.8 \mathrm{~Hz}$ & $2^{\prime \prime \prime}, 3^{\prime \prime \prime}, 5^{\prime \prime \prime}$ \\
$5^{\prime \prime \prime}$ & 18.5 & $0.94,3 \mathrm{H}, \mathrm{d}, J=6.8 \mathrm{~Hz}$ & $2^{\prime \prime \prime}, 3^{\prime \prime \prime}, 4^{\prime \prime \prime}$ \\
$1^{-C O N H}$ & - & $7.59,1 \mathrm{H}, \mathrm{d}, J=8.8 \mathrm{~Hz}$ & $1,2^{\prime \prime \prime}$ \\
$1^{\prime \prime \prime}-\mathrm{CONH} \mathrm{H}_{2}$ & - & $7.50,1 \mathrm{H}, \mathrm{brs}$, overlapped & $1^{\prime \prime \prime}$ \\
& - & $7.06,1 \mathrm{H}, \mathrm{brs}$ & $1^{\prime \prime \prime}, 2^{\prime \prime \prime}$ \\
\hline
\end{tabular}

Table 5 NMR data for compound 4 
most of these cannabimimetic compounds, it is difficult to predict the health risks associated with their use. Hence, constant monitoring and rapid identification of newly tributed NPSs are necessary to prevent drug abuse and serious health risks.

Considering the result of this study, it is obvious that new types of synthetic cannabinoids emerge rapidly, and their combinations in illegal products can be expected to become more and more diverse. The provision of timely and objective information on NPSs and their current trends are thus essential to prevent abuse of drugs.

Acknowledgments We gratefully acknowledge the financial support of the Program of National Science \& Technology Pillar (2011BAK04B06).

\section{Compliance with ethical standards}

Conflict of interest There are no financial or other relations that could lead to a conflict of interest.

Ethical approval This article does not contain any studies with human participants or animals performed by any of the authors.

\section{References}

1. EMCDDA (2015) New psychoactive substances in Europe: an update from the EU Early Warning System. European Monitoring Centre for Drugs and Drug Addiction. http://www.emcdda. europa.eu/publications/2015/new-psychoactive-substances. Accessed May 2015

2. EMCDDA (2014) European drug report 2014: trends and developments. http://www.emcdda.europa.eu/attachements.cfm/ att_228272_EN_TDAT14001ENN.pdf. Accessed Nov 2014

3. SMART (2015) Global smart update: legal responses to NPS: multiple approaches to a multi-faceted problem. http://www.
unodc.org/documents/scientific/Global_SMART_Update_14web.pdf. Accessed Sep 2015

4. Kikura-Hanajiri R, Uchiyama N, Kawamura M, Goda Y (2014) Changes in the prevalence of new psychoactive substances before and after the introduction of the generic scheduling of synthetic cannabinoids in Japan. Drug Test Anal 6:832-839

5. Zuba D, Byrska B (2013) Analysis of the prevalence and coexistence of synthetic cannabinoids in "herbal high" products in Poland. Forensic Toxicol 31:21-30

6. Chung H, Choi H, Heo S, Kim E, Lee J (2014) Synthetic cannabinoids abused in South Korea: drug identifications by the National Forensic Service from 2009 to June 2013. Forensic Toxicol 32:82-88

7. Banister SD, Moir M, Stuart J, Kevin RC, Wood KE, Longworth M, Wilkinson SM, Beinat C, Buchanan AS, Glass M, Connor M, McGregor IS, Kassiou M (2015) Pharmacology of indole and indazole synthetic cannabinoid designer drugs AB-FUBINACA, ADB-FUBINACA, AB-PINACA, ADB-PINACA,5F-ABPINACA, 5F-ADB-PINACA, ADBICA, and 5F-ADBICA. ACS Chem Neurosci. 6:1546-1559

8. Uchiyama N, Matsuda S, Kawamura M, Kikura-Hanajiri R, Goda Y (2013) Two new-type cannabimimetic quinolinyl carboxylates, QUPIC and QUCHIC, two new cannabimimetic carboxamide derivatives, ADB-FUBINACA and ADBICA, and five synthetic cannabinoids detected with a thiophene derivative $\alpha$-PVT and an opioid receptor agonist AH-7921 identified in illegal products. Forensic Toxicol 31:223-240

9. Uchiyama N, Matsuda S, Wakana D, Kikura-Hanajiri R, Goda Y (2013) New cannabimimetic indazole derivatives, $N$-(1-amino-3methyl-1-oxobutan-2-yl)-1-pentyl-1 $H$-indazole-3-carboxamide (AB-PINACA) and $N$-(1-amino-3-methyl-1-oxobutan-2-yl)-1-(4fluorobenzyl)- $1 H$-indazole-3-carboxamide (AB-FUBINACA), identified as designer drugs in illegal products. Forensic Toxicol 31:93-100

10. Buchler IP, Hayes MJ, Hegde SG, Hockerman SL, Jones DE, Kortum SW, Rico JG, Tenbrink RE, Wu KK (2009) Indazole derivatives as $\mathrm{CB}_{1}$ receptor modulators unflagging work flagging work or and their preparation and use in the treatment of $\mathrm{CB}_{1}$ mediated diseases. Patent: WO/2009/106982 September, 2009

11. http://www.caymanchem.com/app/template/SpectralLibrary.vm. Accessed 24 April 2014 